\title{
PENERAPAN NSPM BIDANG KESELAMATAN TERHADAP BAHAYA KEBAKARAN DALAM PEMBANGUNAN INFRASTRUKTUR PERUMAHAN DAN PERMUKIMAN
}

\author{
Achmad Hidajat Effendi dan Suprapto
}

\begin{abstract}
Basically Ministry of Public Works has issued a number of norms, standard, guidelines and manuals (hereinafter named as NSPM). The questions arises on how far such issued NSPMs particularly related to buildings and housings have fulfilled the need of the users. This is the intention of this research. The methods used comprises survey and interview, gathering field data and proceeded through statistical analysis. The results of research which are focused on SNI 03-1746-2000 concerning means of escape, SNI 03-3989-2000 on sprinkler systems and SNI 03-1745-2000 pertaining standpipe and hose showed a significant data. About $76.5 \%$ of the respondent know these standards, however $42.2 \%$ of the respondent suggested to increase dissemination. $41.9 \%$ of the respondent do not clearly understand the substances. $44.1 \%$ of the respondent suggested to revise the standards, while a more detailed technical guidelines were suggested to be made by $71.4 \%$ of the respondent.
\end{abstract}

Keywords: NSPM, buildings and housings, Indonesia National Standard (SNI), fire protection, revision and dissemination.

\section{PENDAHULUAN}

\subsection{Latar Belakang}

Perkembangan sektor industri dewasa ini, tidak terkecuali di lingkungan industri konstruksi menuntut penerapan standarisasi secara konsisten. Meningkatnya tuntutan akan kwalitas konstruksi yang dikaitkan dengan kehandalan, efisiensi biaya operasi, energi serta sustainability, tidak terlepas dari penerapan standarisasi dan perangkat assessment-nya, seperti sertifikasi, akreditasi sarana uji, penandaan dan labelisasi.

Di lingkungan Departemen Pekerjaan Umum, standarisasi merupakan salah satu unsur pengaturan dalam rangka pencapaian kwalitas pekerjaan konstruksi, yang dikenal dengan istilah NSPM yakni norma, standar, pedoman dan manual.

Perkembangan ke arah perpacuan pertumbuhan ekonomi nasional termasuk percaturan globalisasi berdampak kepada meningkatnya tuntutan akan kontrol kwalitas dengan berbagai aspeknya, termasuk tuntutan akan harmonisasi standar (standard alignment), pengakuan atas hak-hak intelektual dan peniadaan hambatan tarif perdagangan (free trade barrier) menuju perdagangan bebas dunia, yang kesemuanya itu bermuara pada pemberlakuan standar dan regulasi teknis yang mendukung. Dalam kaitan ini, semakin dituntut dan dibutuhkannya NSPM yang berkwalitas, teruji dan mantap, bukan semata-mata pada jumlah NSPM yang disusun.

NSPM merupakan tolok ukur dalam menjamin mutu suatu produk pembangunan infrastruktur termasuk dalam hal ini, infrastruktur perumahan dan permukiman. NSPM diperlukan sebagai acuan dalam menjamin mutu konstruksi. Tanpa itu mutu produk konstruksi tidak dapat diandalkan, dan tidak memiliki daya saing. NSPM atau khususnya SNI memuat persyaratan minimal yang harus dipenuhi guna menjamin kwalitas produk yang prima. Di negara-negara maju persyaratan teknis tersebut kini sudah beranjak ke bentuk persyaratan kinerja (performance-based), menunjukkan bahwa tolok ukur kwalitas produk merupakan hal yang sangat esensial. Tidak heran banyak produk negara maju termasuk produk konstruksi memiliki kehandalan yang tinggi.

Kondisi di Indonesia masih cukup memprihatinkan dengan meningkatnya berbagai kegagalan struktur dan konstruksi baik yang terjadi pada bangunan gedung, bangunan tranportasi dan juga pada bangunan air. Kejadian seperti kebakaran, keretakan bangunan, keruntuhan jembatan dan kerusakan bangunan jalan serta kejadian banjir dan genangan air, mendorong ke arah pemikiran sejauh mana kehandalan bangunan atau konstruksi yang telah dibangun tersebut. Menjadi pertanyaan pula sejauh mana NSPM sebagai tolok ukur kwalitas konstruksi telah digunakan dan masih sesuaikah dengan kondisi dan tuntutan pembangunan saat ini.

Berkaitan dengan hal tersebut, diperlukan suatu evaluasi dalam rangka mengkaji hal-hal seperti sejauh mana NSPM yang selama ini disusun konsisten satu sama lainnya menyangkut peristilahan, definisi dan substansinya serta bagaimana pula pemberlakuan NSPM tersebut, sehingga menjadi 
acuan dalam setiap tahapan proses pembangunan.

\section{PERMASALAHAN}

Sesuai hasil survey awal yang dilakukan Badan Penelitian dan Pengembangan PU, Departemen Pekerjaan Umum dalam program sosialisasi dan advis teknis (2003-2004) memperlihatkan adanya indikasi masih belum efektifnya penerapan NSPM terkait dengan programprogram pembangunan infrastruktur perumahan dan permukiman yang berkembang.

Hal-hal yang menyangkut substansi, kemudahan dalam penerapan, tuntutan kekinian, dan updating referensi nampaknya masih perlu diperbaiki.

Berdasarkan hasil survey diatas, maka permasalahan dalam penerapan NSPM dalam pembangunan infrastruktur perumahan dan permukiman, adalah sebagai berikut:

a. Sejauh mana NSPM yang selama ini disusun telah diketahui eksistensinya oleh masyarakat pengguna (users)?;

b. Sejauh mana NSPM yang selama ini disusun telah dipahami dan diterapkan di lapangan?;

c. Sejauh mana NSPM yang selama ini disusun telah mampu menjawab permasalahan yang terjadi atau timbul dalam praktek lapangan?;

d. Apa kendala-kendala yang dijumpai dalam penerapan NSPM sebagai pemandu mutu pembangunan infrastruktur perumahan dan permukiman?;

e. Pokok-pokok substansi apa yang perlu diperbaiki atau direvisi dalam rangka peningkatan kwalitas NSPM dan penerapannya di lapangan?;

f. Sejauh mana NSPM-NSPM yang selama ini disusun konsisten satu sama lainnya menyangkut peristilahan, definisi dan substansinya?;

g. Bagaimana pola pemberlakuan NSPM tersebut, sehingga menjadi acuan dalam setiap tahapan proses pembangunan?.

Ketujuh pertanyaan tersebut, merupakan landasan dalam melakukan penelitian menyangkut NSPM yang saat ini dilakukan oleh Pusat Litbang Permukiman, Badan Litbang PU, Departemen Pekerjaan Umum.
Untuk itu maka NSPM yang telah disusun dan keberadaannya diperlukan untuk meningkatkan kwalitas pelayanan prasarana dan sarana ke-PU-an, terutama di bidang perumahan dan permukiman akan dievaluasi guna menjawab pertanyaan tersebut diatas.

\subsection{Tujuan Penelitian}

Melakukan penelitian atau evaluasi menyangkut penerapan NSPM yang telah disusun selama ini, sejauh mana kesesuaiannya dengan kebutuhan di lapangan, bahan-bahan masukan umum apakah yang perlu dicantumkan dalam memperbaiki kwalitas substansi atau materi NSPM, dan bagaimana upaya untuk meningkatkan penerapan NSPM tersebut kepada pihak-pihak yang terlibat dalam pembangunan infrastruktur, khususnya dalam perumahan dan permukiman.

\subsection{Lingkup Penelitian}

Pada penelitian penerapan NSPM ini, ruang lingkup bahasan dibatasi sesuai bidang keakhlian yaitu keselamatan terhadap bahaya kebakaran, meliputi tiga jenis standar sebagai berikut:

a. SNI No. 03-1746-2000 tentang Tata Cara Perencanaan dan Pemasangan Sarana Jalan Keluar;

b. SNI No. 03-3989-2000 tentang Tata Cara Perencanaan dan Pemasangan Sistem Sprinkler Otomatik untuk Pencegahan Bahaya Kebakaran pada Bangunan Gedung.

c. SNI No. 03-1745-2000 tentang Tata Cara Perencanaan dan Pemasangan Sistem Pipa Tegak dan Slang untuk Pencegahan bahaya Kebakaran pada Bangunan Gedung.

\section{TINJAUAN TEORITIS}

\subsection{Posisi NSPM dalam Hierarki Instrumen Pengaturan}

Sistem pengaturan di Indonesia mengacu kepada model STPI (Science Technology and Policy Implementation) terdiri atas 5 elemen yakni policy atau kebijakan, peraturan perundang-undangan (legel devices), kelembagaan, mekanisme operasional dan pranata sebagaimana diperlihatkan pada gambar berikut. 


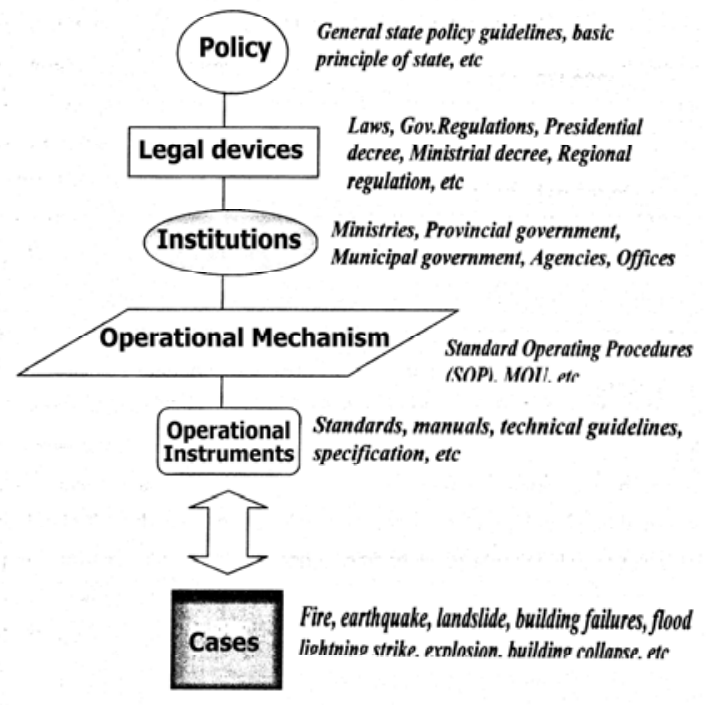

Gambar Hierarki Elemen Pengaturan (STPI).

Kebijakan dalam hal ini contohnya pada masa orde baru adalah GBHN, sekarang Propenas atau RPJM yang ditetapkan oleh MPR dan DPR yang menjadi landasan kebijakan nasional atau sebagai payung dari disusunnya peraturan - peraturan dibawahnya. Peraturan perundang-undangan adalah setingkat dibawah kebijakan, merupakan peraturan untuk mengatur sesuatu, misalnya Undang-Undang yang mengatur Bangunan Gedung yakni UndangUndang Bangunan Gedung No. 28/2002.

Peraturan lainnya yang dikeluarkan oleh Daerah misalnya Perda masuk dalam level ini. Selanjutnya kelembagaan atau institusi adalah lembaga Pemerintah Pusat maupun Daerah yang melaksanakan dan mengawasi serta memonitor diberlakukannya peraturan-peraturan tersebut.

Dalam mengimplementasikan hal-hal yang diatur dalam peraturan, maka lembaga atau institusi menyusun mekanisme operasional yang memberikan acuan tindakan bagi institusi tersebut baik secara sendiri-sendiri maupun dengan kerjasama dengan instansi lainnya, melaksanakan apa yang tertulis dalam peraturan perundang-undangan tersebut. Inilah yang disebut mekanisme operasional yang memiliki strata lebih rendah dari institusi atau strata keempat. Agar mekanisme operasional berjalan baik sesuai dengan tertib pembangunan dan memenuhi persyaratan teknis keamanan, keselamatan, kesehatan dan kenyamanan dan sebagainya, maka diperlukan seperangkat instrumen operasi atau pranata. Ini mencakup standar, pedoman dan manual atau NSPM. Jadi NSPM merupakan alat pengaturan yang posisinya ada pada strata kelima dibawah mekanisme operasional.

\subsection{Urgensi Evaluasi NSPM}

NSPM merupakan instrumen pengaturan yang bersifat dinamis. Sifat dinamis tersebut diartikan bahwa NSPM mengikuti perkembangan Iptek, namun tetap berpijak pada landasan nasional dan memperhatikan taraf kemajuan masyarakat pengguna. Pada saat ini penyusunan NSPM mengacu kepada standar-standar internasional.

Muncul berbagai istilah seperti adopsi, adaptasi dan modifikasi. Sifat mengacu ini didasarkan pada tuntutan keterujian dari suatu standar. Standar-standar internasional yang dikeluarkan oleh berbagai Badan seperti ANSI, NFPA, ASTM dan ISO misalnya merupakan karya yang di-backup oleh sekian ratus kali pengujian sehingga tidak diragukan lagi dan diterima oleh konvensi internasional sebagai standar.

Keterujian ini didukung pula oleh kelembagaan dan sistem yang mendukung dengan diaturnya berbagai elemen standarisasi seperti akreditasi laboratorium uji, sertifikasi, labelisasi dan penandaan. Siapa yang meragukan label FM atau UL misalnya yang telah mendunia dalam masalah standard assessment. Namun sementara itu ada dukungan kuat terhadap pemunculan standarstandar nasional hasil dari berbagai inovasi dan telah dilakukan percobaannya berulang kali. Mana yang akan dianut dan diterapkan, kemungkinan perlu diklarifikasi oleh BSN.

\subsection{NSPM yang Dievaluasi}

Hal-hal penting dalam evaluasi NSPM adalah sejauh mana pemberlakuan standar-standar wajib menyangkut kehandalan bangunan ditinjau dari aspek ketahanan gempa, keselamatan terhadap bahaya kebakaran, duralibilitas bahan dan pengendalian pencemaran lingkungan, telah sesuai dengan kebutuhan yang ada.

Dalam kaitan inilah, penelitian ini dilakukan khususnya dalam mengantisipasi dampak bencana (natural maupun man made) yang cenderung meningkat, tuntutan pembangunan infrastruktur, serta dalam mendukung pemberlakuan dan penerapan Undang-undang Bangunan Gedung No. 28/2000 beserta peraturan-peraturan pelaksanaannya. Dengan akan diterbitkannya Undang-undang tentang "Standarisasi Nasional", maka kegiatan penelitian ini memiliki nilai strategis. 


\section{METODE PENELITIAN}

Metode yang digunakan dalam penelitian ini lebih menekankan kepada pencarian data dan informasi menyangkut penerapan NSPM selama ini. Oleh karena itu kegiatan yang dilakukan meliputi survey lapangan yang dilaksanakan pada beberapa kota terpilih (Jakarta, Semarang, Surabaya, Denpasar, Mataram, Makasar, Manado, Banjarmasin, Medan, Padang, Palembang, dan Batam),

diskusi teknis dan wawancara-wawancara, pengamatan praktek lapangan, komunikasi dengan tenaga akhli dari kalangan konsultan, perguruan tinggi, pejabat dilingkungan Departemen PU, Pemerintah Daerah, Dinas-

dinas Teknis di daerah, kontraktor, para praktisi dan individual maupun badan yang terlibat dalam penerapan NSPM.

Secara garis besar kegiatan penelitian meliputi:

a. Inventarisasi NSPM wajib (menyangkut antara lain keselamatan terhadap bahaya kebakaran);

b. Penetapan NSPM/SNI yang akan dievaluasi melalui kesepakatan dalam rapat teknis dan diskusi dengan nara sumber;

c. Evaluasi penerapan NSPM terpilih tersebut dilaksanakan melalui survey dan wawancara di lapangan dikaitkan dengan proses membangun;

d. Identifikasi pokok-pokok substansi yang perlu di-revisi dalam NSPM/SNI yang dibahas dengan nara sumber dan stakeholder terkait lewat rapat teknis;

e. Pengecekan terhadap metode penerapan NSPM/SNI termasuk ketersediaan pedoman teknis yang mendukung penerapan.

Untuk membantu dalam rangka pencarian data, maka disusun suatu kuesioner yang mencakup pertanyaan-pertanyaan sebagai berikut :

1) Sejauh mana responden mengenal SNI tersebut?;

2) Penyebab mengapa SNI kurang dikenal/diketahui?;

3) Apabila responden mengetahui SNI, apakah digunakan dalam pelaksanaan pembangunan bangunan gedung?;

4) Sebab-sebab SNI tidak digunakan dalam pelaksanaan pembangunan?;

5) Apakah responden memahami/mengerti akan substansi yang diatur atau yang dipersyaratkan dalam standar tersebut?;
6) Apakah responden menjumpai beberapa pasal atau bagian dari standar tersebut yang kurang jelas atau rancu dan sebutkan di bagian mana?;

7) Menurut responden apakah substansi standar tersebut mampu menjawab permasalahan yang terjadi di lapangan?;

8) Apakah responden menggunakan pula peraturan atau standar lainnya disamping SNI tersebut?;

9) Menurut responden apakah standar-standar yang dikemukakan tersebut harus sudah diperbaiki atau direvisi?;

10) Kaitan dengan penerapan standar, apakah perlu disusun suatu petunjuk atau pedoman teknis untuk membantu memberikan penjelasan terhadap substansi standar tersebut?.

Sebagaimana telah disebutkan diatas, bahwa teknik pengumpulan data dari kegiatan penelitian ini adalah menggunakan instrumen kwesioner disebarkan kepada 105 responden, dengan analisis data menggunakan skala Guttman dengan perhitungan dilakukan seperti pada Skala Likert. Skor 3 untuk jawaban ya/tidak ada sosialisasi/substansi kurang jelas, skor 2 untuk jawaban tidak/tidak ada instruksi/substansi kurang sesuai, dan skor 1 untuk jawaban tidak tahu/belum tahu/tidak terkait dengan pekerjaan/ tidak seluruhnya/belum mempelajari. Dari pengumpulan data tersebut, jawaban responden dikompilasi pada tabel, sebagai berikut: 
Tabel Rekapitulasi Jawaban Kuesioner Keselamatan terhadap Bahaya Kebakaran

\begin{tabular}{|c|l|c|c|c|}
\hline No. & \multicolumn{1}{|c|}{ Pertanyaan/Pernyataan } & \multicolumn{1}{|c|}{ Alternatif Jawaban } \\
\cline { 2 - 5 } & \multicolumn{1}{|c|}{$\mathbf{3}$} & $\mathbf{2}$ & $\mathbf{1}$ \\
\hline 1. & $\begin{array}{l}\text { Apakah Bpk/Ibu mengenal atau mengetahui adanya standar SNI No. 03-1746- } \\
\text { 2000; No. 03-3989-2000 dan No. 03-1745-2000? }\end{array}$ & 56 & 35 & 3 \\
\hline 3. & $\begin{array}{l}\text { Apabila mengenal atau mengetahui standar SNI No. 03-1746-2000; } \\
\text { No. 03-3989-2000 dan No. 03-1745-2000, apakah Bpk/ibu } \\
\text { menggunakan sebagai acuan dalam perencanaan atau pelaksanaan } \\
\text { pembangunan bangunan gedung? }\end{array}$ & 51 & 15 & 16 \\
\hline 4. & $\begin{array}{l}\text { Apabila Bpk/Ibu tidak menggunakan standar SNI No. 03-1746-2000; } \\
\text { No. 03-3989-2000 dan No. 03-1745-2000, maka hal ini disebabkan? }\end{array}$ & 5 & 14 & 33 \\
\hline 5. & $\begin{array}{l}\text { Apakah Bpk/Ibu memahami substansi yang diatur atau yang } \\
\text { dipersyaratkan dalam standar SNI No. 03-1746-2000, No. 03-3989- } \\
\text { 2000 dan No. 03-1745-2000? }\end{array}$ & 19 & 19 & 37 \\
\hline 6. & $\begin{array}{l}\text { Apakah Bpk/Ibu menjumpai ada beberapa pasal atau bagian dari } \\
\text { standar SNI No. 03-1746-2000; No. 03-3989-2000 dan No. 03-1745- } \\
\text { 2000, yang kurang jelas atau rancu? }\end{array}$ & 4 & 18 & 46 \\
\hline 7. & $\begin{array}{l}\text { Apakah substansi ketiga standar tersebut mampu menjawab } \\
\text { permasalahan yang terjadi di lapangan? }\end{array}$ & 38 & 5 & 35 \\
\hline 8. & $\begin{array}{l}\text { Apakah Bpk/lbu menggunakan pula peraturan atau standar lainnya, } \\
\text { disamping ketiga SNI tersebut? }\end{array}$ & 35 & 42 & 3 \\
\hline 9. & $\begin{array}{l}\text { Menurut Bpk/Ibu apakah standar SNI No. 03-1746-2000; No. 03-3989- } \\
\text { 2000 dan No. 03-1745-2000, harus sudah direvisi atau diperbaiki } \\
\text { substansinya? }\end{array}$ & 28 & 14 & 27 \\
\hline 10 & $\begin{array}{l}\text { Terkait dengan standar SNI No. 03-1746-2000; No. 03-3989-2000 dan } \\
\text { No. 03-1745-2000, apakah perlu disusun suatu petunjuk/pedoman } \\
\text { teknis untuk membantu memberikan penjelasan terhadap substansi } \\
\text { ketiga standar tersebut? }\end{array}$ & 71 & 2 & 8 \\
\hline
\end{tabular}

Sumber : Hasil Penelitian Pusat Litbang Permukiman 2006.

1= Tidak Tahu; Tidak terkait dengan pekerjaan; Belum tahu, Tidak seluruhnya; Belum mempelajari

2= Tidak; Tidak ada instruksi; Substansi kurang Sesuai

3= Ya; Tidak ada sosialisasi; Substansi kurang jelas

No. 1

Skor 3 = 56; skor 2 = 35 dan skor $1=3$.

Jumlah skor untuk jawaban 3: 56 × $3=168$

Jumlah skor untuk jawaban 2: $35 \times 2=70$

Jumlah skor untuk jawaban 1: $3 \times 1=3$

Jumlah skor $=241$

Jumlah skor tertinggi (ideal): $3 \times 105=315$ (Ya)

Jumlah skor terendah: $1 \times 105=105$ (Tidak tahu)

Perhitungan: $241 / 315 \times 100 \%=76,51 \%$

Jawaban kuesioner No. 1 dengan jumlah responden 105, SNI No. 03-1746-2000; No.033989-2000 dan No. 03-1745-2000, telah dikenal, di kalangan pemerintah, perguruan tinggi, konsultan dan sebagainya, hal tersebut terbukti dari perhitungan dan kriteria interpretasi skor, sebagai berikut:

Kriteria interpretasi skor: 76,51 \%

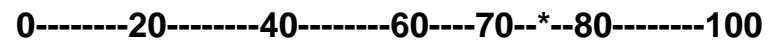

\section{No. 2}

Skor 3 = 38; skor $2=5$ dan skor $1=9$.

Jumlah skor untuk jawaban 3: $38 \times 3=114$

Jumlah skor untuk jawaban 2: $5 \times 2=10$

Jumlah skor untuk jawaban 1: $9 \times 1=9$

Jumlah skor $=133$

Jumlah skor tertinggi (ideal): $3 \times 105=315$ (Tidak ada sosialisasi)

Jumlah skor terendah: $1 \times 105=105$ (Tidak terkait dengan pekerjaan)

Perhitungan: $133 / 315 \times 100 \%=42,22 \%$

Jawaban kuesioner No. 2 dengan jumlah responden 105, tidak mengenal atau mengetahui SNI No. 03-1746-2000; No.03-3989-2000 dan No. 03-1745-2000, karena kurang sekali 
sosialisasi, hal tersebut terbukti dari perhitungan dan kriteria interpretasi skor, sebagai berikut:

Kriteria interpretasi skor: 42,22 \%

0-------20-------40-*-45------60-------80--------100

\section{No. 3}

Skor $3=51$; skor 2 = 15 dan skor $1=16$.

Jumlah skor untuk jawaban 3: $51 \times 3=153$

Jumlah skor untuk jawaban 2: $15 \times 2=30$

Jumlah skor untuk jawaban 1: $16 \times 1=16$

Jumlah skor $=199$

Jumlah skor tertinggi (ideal): 3 x $105=315$ (Ya)

Jumlah skor terendah: $1 \times 105=105$ (Tidak tahu)

Perhitungan: $199 / 315 \times 100 \%=63,17 \%$

Jawaban kuesioner No. 3 dengan jumlah responden 105, SNI No. 03-1746-2000; No.033989-2000 dan No. 03-1745-2000, telah digunakan sebagai acuan dalam perencanaan atau pelaksanaan pembangunan gedung, hal tersebut terbukti dari perhitungan dan kriteria interpretasi skor, sebagai berikut:

Kriteria interpretasi skor: 63,17\%

0-------20-------40--------60-*-65------80--------100

\section{No. 4}

Skor 3 = 5; skor 2 = 14 dan skor $1=33$.

Jumlah skor untuk jawaban 3: $5 \times 3=15$

Jumlah skor untuk jawaban 2: $14 \times 2=28$

Jumlah skor untuk jawaban 1: $33 \times 1=33$

Jumlah skor $=76$

Jumlah skor tertinggi (ideal): $3 \times 105=315$ (Substansi kurang jelas)

Jumlah skor terendah: 1 × $105=105$ (Belum tahu)

Perhitungan: $76 / 315 \times 100 \%=24,13 \%$

Jawaban kuesioner No. 4 dengan jumlah responden 105, tidak menggunakan SNI No. 031746-2000; No.03-3989-2000 dan No. 03-17452000, disebabkan substansi tidak jelas, hal tersebut terbukti dari perhitungan dan kriteria interpretasi skor, sebagai berikut:

Kriteria interpretasi skor: 24,13\%

$$
\text { 0--------20-*--30----40--------60--------80--------100 }
$$

\section{No. 5}

Skor 3 = 19; skor 2 = 19 dan skor $1=37$. Jumlah skor untuk jawaban 3: $19 \times 3=57$ Jumlah skor untuk jawaban 2: $19 \times 2=38$ Jumlah skor untuk jawaban 1: $37 \times 1=37$ Jumlah skor $=132$
Jumlah skor tertinggi (ideal): 3 x $105=315$ (Ya)

Jumlah skor terendah: 1 × $105=105$ (Tidak seluruhnya)

Perhitungan: $132 / 315 \times 100 \%=41,90 \%$

Jawaban kwesioner No. 5 dengan jumlah responden 105, substansi yang diatur atau yang dipersyaratkan dalam SNI No. 03-1746-2000; No.03-3989-2000 dan No. 03-1745-2000, disebabkan kurang memahami, hal tersebut terbukti dari perhitungan dan kriteria interpretasi skor, sebagai berikut:

Kriteria interpretasi skor: 41,90 \%

0-------20-------40*---50----60-------80-------100

\section{No. 6}

Skor $3=4$; skor $2=18$ dan skor $1=46$.

Jumlah skor untuk jawaban 3: $4 \times 3=12$

Jumlah skor untuk jawaban 2: $18 \times 2=36$

Jumlah skor untuk jawaban 1: $46 \times 1=46$

Jumlah skor $=94$

Jumlah skor tertinggi (ideal): 3 x $105=315$ (Ya)

Jumlah skor terendah: 1 × $105=105$ (Belum mempelajari)

Perhitungan: $94 / 315 \times 100 \%=29,84 \%$

Jawaban kuesioner No. 6 dengan jumlah responden 105, tentang adanya beberapa pasal atau bagian dari SNI No. 03-1746-2000; No.033989-2000 dan No. 03-1745-2000 yang kurang jelas atau rancu, responden menjawab kurang mempelajari, hal tersebut terbukti dari perhitungan dan kriteria interpretasi skor, sebagai berikut:

Kriteria interpretasi skor: 29,84\%

0-------20---*30----40--------60--------80--------100

\section{No. 7}

Skor 3 = 38; skor $2=5$ dan skor $1=35$.

Jumlah skor untuk jawaban 3: 38 × $3=114$

Jumlah skor untuk jawaban 2: $5 \times 2=10$

Jumlah skor untuk jawaban 1: $35 \times 1=35$

Jumlah skor $=159$

Jumlah skor tertinggi (ideal): 3 x $105=315$ (Ya)

Jumlah skor terendah: 1 × $105=105$ (Tidak tahu)

Perhitungan: $159 / 315 \times 100 \%=50,48 \%$

Jawaban kuesioner No. 7 dengan jumlah responden 105, responden menjawab substansi ketiga SNI No. 03-1746-2000; No.03-3989-2000 dan No. 03-1745-2000, mampu menjawab permasalahan yang terjadi di lapangan hal tersebut terbukti dari perhitungan dan kriteria interpretasi skor, sebagai berikut: 
Kriteria interpretasi skor: 50,48 \%

0-------20--------40----50*---60--------80--------100

No. 8

Skor $3=35$, skor $2=42$ dan skor $1=3$.

Jumlah skor untuk jawaban 3: $35 \times 3=105$

Jumlah skor untuk jawaban 2: $42 \times 2=84$

Jumlah skor untuk jawaban 1: $3 \times 1=3$

Jumlah skor $=192$

Jumlah skor tertinggi (ideal): 3 x $105=315$ (Ya)

Jumlah skor terendah: 1 × $105=105$ (Tidak tahu)

Perhitungan: $192 / 315 \times 100 \%=60,95 \%$

Jawaban kuesioner No. 8 dengan jumlah responden 105, responden menjawab bahwa selain ketiga SNI No. 03-1746-2000; No.033989-2000 dan No. 03-1745-2000, menggunakan pula peraturan atau standar lain, hal tersebut terbukti dari perhitungan dan kriteria interpretasi skor, sebagai berikut:

Kriteria interpretasi skor: 60,95\%

0---------20--------40--------60*---70----80--------100

\section{No. 9}

Skor $3=28$, skor $2=14$ dan skor $1=27$.

Jumlah skor untuk jawaban 3: $28 \times 3=84$

Jumlah skor untuk jawaban 2: $14 \times 2=28$

Jumlah skor untuk jawaban 1: $27 \times 1=27$

Jumlah skor $=139$

Jumlah skor tertinggi (ideal): 3 x $105=315$ (Ya)

Jumlah skor terendah: 1 × $105=105$ (Tidak tahu)

Perhitungan: $139 / 315 \times 100 \%=44,13 \%$

Jawaban kuesioner No. 9 dengan jumlah responden 105, responden menjawab ketiga SNI No. 03-1746-2000; No.03-3989-2000 dan No. 03-1745-2000, perlu direvisi atau diperbaiki substansinya, hal tersebut terbukti dari perhitungan dan kriteria interpretasi skor, sebagai berikut:

Kriteria interpretasi skor: 44,13\%

0-------20-------40-*--50----60-------80--------100

\section{No. 10}

Skor $3=71$, skor $2=2$ dan skor $1=8$.

Jumlah skor untuk jawaban 3: $71 \times 3=213$

Jumlah skor untuk jawaban 2: $2 \times 2=4$

Jumlah skor untuk jawaban 1: $8 \times 1=8$

Jumlah skor $=225$

Jumlah skor tertinggi (ideal): 3 x $105=315$ (Ya)
Jumlah skor terendah: 1 × $105=105$ (Tidak tahu)

Perhitungan: $225 / 315 \times 100 \%=71,43 \%$

Jawaban kusioner No. 10 dengan jumlah responden 105, responden menjawab ketiga SNI No. 03-1746-2000; No.03-3989-2000 dan No. 03-1745-2000, perlu sekali disusun suatu petunjuk/pedoman teknis untuk membantu memberikan penjelasan terhadap substansi dari ketiga standar tersebut, hal ini terbukti dari perhitungan dan kriteria interpretasi skor, sebagai berikut:

Kriteria interpretasi skor: $\mathbf{7 1 , 4 3 \%}$

0--------20--------40--------60----70*---80--------100

\section{BAHASAN}

Hasil survey lapangan dan hasil analisis dalam penelitian penerapan NSPM bidang keselamatan terhadap bahaya kebakaran diperoleh hal-hal berikut, yang terkait dengan masalah kesesuaian NSPM/SNI bidang keselamatan terhadap bahaya kebakaran dengan kebutuhan lapangan, maka diperoleh informasi, sebagai berikut:

a. Standar-standar tentang keselamatan terhadap bahaya kebakaran telah cukup dikenal di masyarakat pengguna $(76,51 \%$ responden);

b. Sebanyak $42,22 \%$ responden mengatakan penyebab kurang dikenalnya SNI tentang keselamatan terhadap bahaya kebakaran adalah kurang sekali sosialisasi khususnya terhadap instansi atau pihak-pihak terkait dengan masalah kebakaran;

c. $63,17 \%$ responden mengatakan bahwa ketiga SNI tentang keselamatan terhadap bahaya kebakaran digunakan sebagai acuan dalam perencanaan dan pelaksanaan pembangunan bangunan gedung;

d. Sejumlah $24,13 \%$ responden kurang diterapkannya SNI tentang keselamatan terhadap bahaya kebakaran disebabkan ketidak jelasan materi (substansi);

e. $41,90 \%$ responden mengatakan kurang memahami substansi kertiga SNI tentang keselamatan terhadap bahaya kebakaran;

f. Sejumlah 29,84\% responden menyatakan kurang mempelajari terdapatnya beberapa pasal yang kurang jelas atau rancu pada ketiga SNI tersebut;

g. Sejumlah $50,48 \%$ responden mengatakan ketiga SNI tentang keselamatan terhadap bahaya kebakaran mampu menjawab permasalahan di lapangan; 
h. $60,95 \%$ responden menggunakan pula standar atau SNI lain, selain SNI tentang keselamatan terhadap bahaya kebakaran;

i. $44,13 \%$ responden menyatakan ketiga SNI tentang keselamatan terhadap bahaya kebakaran perlu dan mengusulkan untuk dilakukan perbaikan (revisi);

j. $\quad 71,43 \%$ responden menyatakan perlu sekali, dan mengusulkan untuk dibuatkan pedoman teknis, untuk membantu memberikan penjelasan terhadap substansi dari ketiga SNI tersebut yang tidak jelas.

\section{KESIMPULAN}

a. Secara keseluruhan NSPM atau SNI bidang keselamatan terhadap bahaya kebakaran telah dikenal masyarakat pengguna, namun masih perlu sosialisai dilakukan di seluruh daerah;

b. Dalam rangka peningkatan penerapan NSPM/SNI bidang keselamatan terhadap bahaya kebakaran masih perlu dilakukan penyempurnaan/perbaikan dan revisi disamping perlunya disusun pedoman / petunjuk teknis yang lebih sederhana dan praktis;

c. Perlunya peningkatan akses dan kemudahan dalam memperoleh buku-buku NSPM/SNI;

d. Perlunya suatu standing committee pada setiap aspek dalam rangka terus memantau dan mengkaji kwalitas penerapan NSPM sebagai pemandu mutu pembangunan;

e. Masih diperlukannya kebijakan dan strategi yang mantap dalam rangka penerapan NSPM di lingkungan Departemen Pekerjaan Umum;

f. Surat Keputusan Menteri menyangkut SNI Wajib perlu diralat istilah pengesahan menjadi pemberlakuan;

g. Perlu ditindak lanjuti usulan Kepala Badan Litbang PU agar setiap proyek infrastruktur ke-PU-an menggunakan NSPM/SNI yang dikukuhkan lewat Peraturan Menteri PU dan setiap pedoman/petunjuk teknis diberlakukan dengan Surat Keputusan Kepala Badan Litbang PU.

\section{DAFTAR PUSTAKA}

1. Departemen Pekerjaan Umum, 1998, Keputusan Menteri PU No. 44/KPTS/1998, tentang Persyaratan Teknis Bangunan Gedung, Jakarta.
2. Kantor Menteri Negara PU, 2000, Keputusan Menteri Negara PU No. 10/KPTS/2000, tentang Ketentuan Teknis Pengamanan Terhadap Bahaya Kebakaran pada Bangunan Gedung dan Lingkungan, Jakarta.

3. Peraturan Pemerintah Republik Indonesia, 2005, No. 36 Tahun 2005 tentang Peraturan Pelaksanaan Undang-Undang Nomor 28 Tahun 2002 tentang Bangunan Gedung, Jakarta.

4. Pusat Litbang Permukiman, 2006, Laporan Akhir Aplikasi NSPM Dalam Pembangunan Infrastruktur Perumahan dan Permukiman, Pusat Litbang Permukiman, Badan Litbang PU, Departemen Pekerjaan Umum, Bandung.

5. Riduwan, Drs., M.B.A., 2002, Skala Pengukuran Variabel-Variabel Penelitian, Alfabeta, Bandung.

6. SNI No. 03-1746-2000 tentang Tata Cara Perencanaan dan Pemasangan Sarana Jalan Ke luar, BSN, Jakarta.

7. SNI No. 03-3989-2000 tentang Tata Cara Perencanaan dan Pemasangan Sistem Sprinkler Otomatik untuk Pencegahan Bahaya Kebakaran pada Bangunan Gedung, BSN, Jakarta.

8. SNI No. 03-1745-2000 tentang Tata Cara Perencanaan dan Pemasangan Sistem Pipa Tegak dan Slang untuk Pencegahan bahaya Kebakaran pada Bangunan Gedung, BSN, Jakarta.

9. Suprapto, 2005, Building Regulatory System in Indonesia, Seminar on Fire safe use of Timber in Construction, held in Wellington on $24-26^{\text {th }}$ may 2005.

10. Undang-Undang Republik Indonesia Nomor 28 Tahun 2002, tentang Bangunan Gedung, Jakarta.

\section{BIODATA}

Achmad Hidajat Effendi, lahir di Bandung, 3 Mei 1953, saat ini bekerja di Pusat Penelitian dan Pengembangan Pemukiman, Badan Litbang, Departemen Pekerjaan Umum. Saat ini peneliti menjabat sebagai Peneliti Madya bidang Sains Bangunan.

Suprapto, saat ini bekerja di Pusat Penelitian Kalibrasi Instrumentasi dan Metrologi, Lembaga IImu Pengetahuan Indonesia. Penulis menamatkan pendidikan S1 dan S2 bidang Elektronika Ehime University tahun 1992 dan 1994 dan S3 dari Shinshu University, Jepang tahun 2001. Saat ini penulis menjabat sebagai Peneliti bidang Instrumentasi Optik di Laboratorium Metrologi Radiometeri Fotometri. 
